\title{
PRODUKSI DAN KEUNTUNGAN HASIL TANAMAN CABAI (Capsicum Sp) DI DESA PULANTAN KECAMATAN AWAYAN KABUPATEN BALANGAN PROVINSI KALIMANTAN SELATAN
}

\author{
(Production And Advantages Of Chili Crop (Capsicum sp) In Pulantan Village, Awayan District, \\ Balangan South Kalimantan Province)
}

Bahrun ${ }^{1}$ dan Rohansyah ${ }^{2}$

Faculty of Agricultural, Achmad Yani Banjarmasin's University Jl.A.Yani.km.5,5 Komp.Stadion Lambung Mangkurat Banjarmasin Email $^{1)}$ : bahrun.bn@gmail.com ${ }^{2)}$ : rohansyahsamad@gmail.com

Article Submitted : 30-5-2020

Article Accepted : 04-6-2020

\begin{abstract}
The purpose of this study is technically to determine the implementation of the cultivation of cayenne pepper, economically to find out the amount of costs, revenue, income and profits on the cultivation of cayenne pepper in the Village of Pulantan Awayan District.. Average production of $241.70 \mathrm{~kg}$ / farmer. Average revenue of Rp.12,085,000.00 / farmer, Average Total Cost of Rp. 6,489,268.35 / farmer Average income of Rp.8,105,795.83 / farmer. average profit of Rp. 5,595,731.65 / farmer. The study was conducted in Pulantan Village, Awayan District, Balangan Regency South Kalimantan Province. Data obtained and processed in this study include primary data and secondary data. The research used the puposive method by intentionally taking farmers who specifically planted cayenne peppers. Whereas the sampling technique is done by census (complete enumeration of all elements of the population. The total number of samples taken is 20 farmers. The data collected is processed in tabulation and then analyzed which includes the costs, revenues, income and profits of the farming of Rawit Chili. Average production of $241.70 \mathrm{~kg} /$ farmer. Average income of Rp.12,085,000.00 / farmer, Average Total Cost of Rp. 6,489,268.35 / farmer Average income of Rp8,105,795.83 / farmer. average profit of Rp. 5,595,731.65 / farmer
\end{abstract}

Keywords, farming, production, revenue, total costs, profits

\section{PENDAHULUAN}

Indonesia merupakan negara pertanian, hal ini dapat ditunjukan dari banyaknya jumlah penduduk dan tenaga kerja yang hidup atau bekerja disektor pertanian atau dari produk nasional yang berasal dari pertanian (Mubyarto 1989 : 12).

Petani sebagai pelaku utama dalam bidang pertanian sejauh ini pada umumnya belum memiliki kemampuan dan keterampilan yang memadai untuk dapat merencanakan dan melaksanakan kegiatan pertanian secara maksimal. Pada kenyataannya sebagian besar petani memiliki tingkat pendidikan yang rendah, dan mempunyai kepemilikan lahan yang cukup kecil. Kondisi tersebut selanjutnya mendudukan petani pada posisi yang lemah dalam akses terhadap pengembangan ilmu pengetahuan yang diperlukan untuk memajukan kegiatannya. Kebanyakan petani hanya melaksanakan kegiatanya secara tradisional, tanpa disertai inovasi baru untuk meningkatkan produktifitas yang pada gilirannya akan meningkatkan kesejahteraan (Kasryno, F.2000). 
Usaha pada bidang pertanian bertujuan untuk meningkatkan pendapatan dan kesejahteraan petani, yang berdampak terhadap pertumbuhan ekonomi dan sektor lainnya, termasuk sektor jasa. Pada kegiatan pengembangan disektor pertanian yang berorientasi pasar, eksploitasi lahan yang berlebiahn harus dihindari agar tidak mengganggu produktif dan daya dukung lahan. Lahan potensial dan produktif umtuk kegiatan usahatai harus dioptimalkan agar produktivitasnya dapat berkelanjutan pemanfaatannya, salah satunya dengan selalu memelihara dan menjaga kelestariannya,. (Bappenas 2005)

Cabai rawit (Capsicum frutescens L.) merupakan salah satu tanaman hortikultura dari jenis sayuran yang memiliki buah kecil dengan rasa yang pedas. Jenis atau varietas ini dibudidayakan oleh para petani karena banyak dibutuhkan masyarakat, tidak hanya dalam skala rumah tangga, tetapi juga digunakan dalam skala industri, dan dieksport ke luar negeri. Cabai rawit mempunyai banyak manfaat, yaitu sebagai bumbu masak, bahan campuran industri makanan, dan sebagai bahan kosmetik. Selain manfaat dari buahnya, bagian lain dari tanaman ini seperti batang, daun, dan akarnya juga dapat digunakan sebagai obat obatan (Ashari, 1995).

Di Kalimantan Selatan sendiri cabai rawit dengan luas lahan panen $768 \mathrm{Ha}$ tanaman cabai rawit menghasilkan produksi 3.191 ton atau 4,15 ton/Ha. data dari Badan Pusat Statistik Provinsi Kalimantan Selatan tahun 2018. Di Kabupaten Balangan luas tanam cabai rawit $127 \mathrm{Ha}$, memperoleh produksi 2.135 ton, atau 17,30 ton/Ha. (BPS Kabupaten Balangan 2018).

Desa Pulantan merupakan salah satu desa di Kecamatan Awayan yang membudidayakan tanaman sayuran seperti cabai rawit, jagung, dan sayuran lainnya. Peneliti tertarik untuk melakukan penelitian cabai rawit, karena komoditas cabai rawit telah dibudidayakan secara terus menerus di daerah ini.
Diharapkan dari hasil kegiatan tersebut akan memberikan manfaat dan kesejahteraan bagi petani dan keluarganya.

Adapun kegiatan penelitian di desa ini dimaksudkan untuk melihat dan mengamati kegiatan usahatani cabai rawit, pada satu kali kegiatan musim tanam tahun 2019/2020.

Tujuan penelitian ini secara teknis untuk mengetahui penyelengaraan budidaya cabai rawit, secara ekonomis untuk mengetahui besarnya biaya, penerimaan, pendapatan dan keuntungan pada usahatani cabai rawit di Desa Pulantan Kecamatan Awayan.

\section{METODE PENELITIAN}

\section{Tempat dan Waktu}

Penelitian dilaksanakan di Desa Pulantan Kecamatan Awayan Kabupaten Balangan Provinsi Kalimantan Selatan selama lebih kurang tiga bulan, yaitu dari bulan November 2019 sampai dengan bulan Januari 2020. Kegiatan penelitian dilakukan dalam beberapa tahap, yaitu dari tahapan persiapan sampai dengan penyusunan laporan.

\section{Teknik Pengumpulan dan Sumber Data}

Data yang diperoleh dan diolah pada penelitian ini, meliputi data primer dan data sekunder. Data primer diperoleh dengan cara melakukan wawancara langsung kepada petani cabai rawit (responden) disertai dengan daftar pertanyaan, sedangkan data sekunder diperoleh dari instansi dan dinasdinas terkait yang berhubungan dan relevan dengan penelitian ini.

\section{Teknik Penarikan Contoh}

Penelitian ini menggunakan metode puposive yaitu secara sengaja dengan mengambil petani yang khusus menanam cabai rawit. Sedangkan teknik pengambilan petani sampel dilakukan secara sensus (pencacahan lengkap seluruh elemen populasi), artinya seluruh responden diambil sebagai sampel (Nazir, 1983). Adapun 
jumlah sampel yang diambil seluruhnya sebanyak 20 orang petani.

\section{Analisis Data}

Data yang sudah terkumpul diolah dalam tabulasi dan selanjutnya dianalisa yang meliputi biaya, penerimaan, pendapatan dan keuntungan usahatani Cabai Rawit.

Untuk mengetahui biaya Input (sarana produksi) yang digunakan dalam peneyelenggaraan usahatani Cabai Rawit secara matematis adalah sebagai berikut (Soekartawi,1995; 57) :

TC = TEC + TIC

Dimana :

$\mathrm{TC}=$ Total Cost/ Biaya Total $(\mathrm{Rp})$

$\mathrm{TEC}=$ Total Eksplicit Cost $/$ Biaya Eksplisit Total (Rp)

TIC $=$ Total Implicit Cost / Biaya Implisit Total (Rp)

Menurut (Rahim dan Hastuti, 2007), untuk mengetahui total penerimaan dirumuskan sebagai berikut :

$\mathrm{TR}=\mathrm{Y} \times \mathrm{Py}$

Dimana :

$\mathrm{TR}=$ Total Penerimaan

$\mathrm{Y}=$ produksi yang diperoleh dari suatu usahatani

Py = harga produksi Menurut Syarifuddin A. Kasim,

(1995 ;36), untuk mengetahui pendapatan digunakan rumus sebagai berikut :

$\mathrm{I}=\mathrm{TR}-\mathrm{TEC}$

Dimana :

I = Income / Pendapatan (Rp)

$\mathrm{TR}=$ Total Revenue/Penerimaan Total(Rp)

TEC $=$ Total Explicit $\quad$ Cost/Biaya

Eksplisit Total (Rp)

Untuk mengetahui keuntungan digunakan rumus analisa keuntungan (Soekartawi, 1989) adalah :

$\pi=\mathrm{TR}-\mathrm{TC}$

Dimana :

$\pi \quad=$ Profit / Keuntungan (Rp)

$\mathrm{TR}=$ Total Revenue / Penerimaan Total (Rp)

$\mathrm{TC}=$ Total Cost / Biaya Total (Rp)

\section{HASIL DAN PEMBAHASAN}

\section{Aspek Teknia Budidaya Tanaman Cabai}

1. Persemaiaan

Untuk memulai persemaiaan mulamula mempersiapkan benih yang dibutuhkan sesuasi dengan luas area tanam untuk satu hektar rata - rata yang diperlukan kurang lebih stengah kilogram pastikan lokasi persemaan terhidar dari panas maka diperlukan naungan agar terhindar dari sinar matahari, hujan kelembaban dan kesetabilan suhu harus diperhatikan.

Siapkan polibag kecil diisi dengan tanan yang dicampur sekam tanpa dicampur pupuk lainya karena dapat mempengaruhi pertumbuhan semaian. Sesudah tanah dimasukkan kedalam polibag lalu siram sampai keadaan tanah sngat basar agar menjadi lembab, setelah siap lanjutkan dengan merendam biji benih yang kering dengan tujuan untuk menghilangkan proses dormansi. Kemudiaan tanam biji kedalam polibag, saat menanam biji jangan terlalu dalam agar tidak menghambat pertumbuhan benih setelah itu tutup dengan tanah semai. Penyiraman dilakukan secara teratur gunakan kertas atau karung sebagi penutup untuk menjaga kelembaban. Untuk menghindari kucuran air penyiraman lakukan dengan gembur setelahnya kira kira sekitar 2 minggu maka benih siap tanam.

2. Pengolahan Lahan

Tanah di bajak dibuat bedengan dengan lebar $40-50 \mathrm{~cm}$, dengan tinggi 20 $\mathrm{cm}$. Jarak atar bedengan dengan yang lainya 60-70 cm, setelah itu berikan kapur dolomit diatas bedengan di sertai dengan pupuk kandang. Selanjutnya buat lobang tanam dengan jarak $50 \mathrm{~cm}$ dengan tanaman lainya setelah lubang siap pindahkan bibit dari polibag kedalam lubang yang sudah siap tutup kembali dengan tanah, disarankan untuk pemindahan lebaik pada sore hari untuk menghindari tanaman menjadi layu setelah di pindah kelahan. 
3. Perawatan, Pemeliharaan dan Penyiangan

Pemeliharaan pada usahatani cabai cukup mudah, penyiraman dilakuan pagi sore utuk mengasilkan pertumbuhan yang bagus pada sore penyiraman dilakukan dengan kondisi tanah sangat basah sehingga bnyak air yang dapt diserap tanaman sebagai makanan di malam hari.perawatan dan penyiangan dilakukan 2 minggu sekali sepeti membersihkan gulma dan rumput agar bersih dan tidak tinggi yang bisa menghambat pertumbuhan tanaman.

4. Pemupukan Susulan

Pemupukan susulam dilakukan setelah satu bulan pemupukan dilakukan 2 kali seminggu pupuk yang digunakan pupuk NPK, Urea dan pupuk Cair seperti Grand tonik.

5. Pengendaliaan hama dan Penyakit tanaman

Usahatani cabai biasanya sangat jarang terserang hama dan penyakit namun tidak mungkin tidak diserang hama dan penyakit. Berdasarkan hal tersebut, sebelum teserang hama dan penyakit dilakukan pencegahan dengan penyemprotan seminggu 2 kali dengan insektida sebgai pengendali hama dan penyakit.

6. Panen

Kegiatan panen sudah dapat dilakukan pada saat tanaman berumur 3 bulan sejak dari masa tanam panen dapat dilakukan hingga 6 bulan bahkan bisa lebih dan disarankan menanam cabai di pagi hari.

\section{Aspek Finansial Usahatani Cabai}

Biaya adalah sejumlah korbanan yang diperlukan selama melaksanakan uasahatani cabai rawit. Biaya yang diperhitungkan pada peleitian ini meliputi biaya eksplist dan biaya implisit.

\section{Biaya Eksplisit}

Biaya eksplisit yang dihitung dan dianalisis pada usahatani cabai selama 1 (satu) kali musim tanam, yaitu 3 (tiga) bulan, meliputi biaya sarana produksi, biaya alat perlengkapan dan pajak lahan serta biaya tenaga kerja.

\section{Biaya sarana Produksi}

Lebih jelasnya mengenai biaya sarana produksi pada usahatani cabai dapat dilihat pada Tael 1 berikut ini.

Tabel 1. Rata-rata Biaya Sarana Produksi Usahatani Cabai di Desa Pulantan .

\begin{tabular}{llrr}
\hline No & Uraian & Biaya (Rp) & $\begin{array}{r}\text { Persentasi } \\
(\%)\end{array}$ \\
\hline 1 & Benih & $31.250,00$ & 2,35 \\
2 & Pupuk & $856.350,00$ & 64,53 \\
3 & Obat-obatan & $439.500,00$ & 33,12 \\
\hline & Jumlah & $1.327 .100,00$ & 100 \\
\hline
\end{tabular}

$\overline{\text { Sumber : Hasil Pengolahan Data Primer Tahun } 2020}$

\section{Biaya Penyusutan Alat}

Dengan berkurangnya nilai pakai alat-alat produksi pertanian, maka dapat diadakan perhitungan biaya penyusutan alatalat tahan lama yang mengandung sejumlah nilai pakai yang harus diperhitungkan setiap tahunnya. Biaya penyusutan ini tergantung pada nilai alat saat pembeliaan, usia ekonomis alat, nilai sisa setelah habis jangka ekonomis tersebut (dalam hal ini dianggap nol) dan masa kerja efektif alat pada usahatani jagung. Biaya penyusutan alat dapat dilihat pada Tabel 2 .

Tabel 2. Rata-rata Biaya Penyusutan Alat Pada Usahatani Cabai di Desa Pulantan .

\begin{tabular}{llrr}
\hline No & Uraian & Biaya (Rp) & $\begin{array}{r}\text { Persentasi } \\
(\%)\end{array}$ \\
\hline 1 & Cangkul & $4.791,67$ & 18,31 \\
2 & Parang & $1.375,00$ & 5,25 \\
3 & Mesin Pompa Air & $20.000,00$ & 76,43 \\
\hline & Jumlah & $26.166,67$ & 100,00 \\
\hline
\end{tabular}

Sumber : Pengolahan Data Primer 2020

\section{Biaya tenaga Kerja Luar Keluarga}

Dalam kegiatan usahatani Cabai yang dilaksanakan petani selama satu kali musim tanam, tenaga kerja luar keluarga yang meliputi pengolahan lahan, penyiangan dan panen.

4. Pajak Lahan

Pajak lahan tergantung luas lahan yang dimiliki petani serta masa produksinya. Pajak lahan yang berlaku pada saat pengamatan 55.000,/borong/tahun. Berdasarkan hasil perhitungan di atas biaya 
rata-rata pajak lahan pada usahatani jagung di Desa Pulantan sebesar Rp. 30.937,50,/petani.

\section{Biaya Eksplisit}

Biaya eksplisit meliputi penyusutan alat, pajak lahan, TKLK, dan saprodi. Untuk lebih jelasnya dapat dilihat pada Tabel 3 .

Tabel 3. Biaya Eksplisit Rata-rata yang dikeluarkan pada Usahatani Cabai di Desa Pulantan .

\begin{tabular}{llrc}
\hline No & \multicolumn{1}{c}{ Uraian } & Biaya (Rp) & $\begin{array}{c}\text { Persentasi } \\
(\%)\end{array}$ \\
\hline 1 & Penyusutan alat & $26.166,67$ & 0,66 \\
2 & Pajak lahan & $30.937,50$ & 0,78 \\
3 & Saprodi & $1.327 .100,00$ & 33,35 \\
4 & TKLK & $2.595 .000,00$ & 65,21 \\
\hline & Jumlah & $3.979 .204,17$ & 100,00 \\
\hline
\end{tabular}

Sumber : Pengolahan Data Primer 2020

Dari Tabel 3 diketahui, penggunaan biaya tertingi dan terendah pada petani yaitu biaya tertinggi pada saprodi sedangkan biaya penggunaan terandah pada pajak lahan.

\section{Biaya Implisit}

Biaya implisit yang diperhitungkan pada usahatani cabai meliputi biaya tenaga kerja dalam keluarga (TKDK) dan bunga modal. Rata-rata biaya implisit dapat dilihat pada Tabel 4 berikut.

Tabel 4. Rata-rata Biaya Implisit Pada Usahatani Cabai Rawit di Desa Pulantan

\begin{tabular}{llcr}
\hline No & \multicolumn{1}{c}{ Uraian } & $\begin{array}{c}\text { Biaya } \\
(\mathrm{Rp})\end{array}$ & $\begin{array}{c}\text { Persentasi } \\
(\%)\end{array}$ \\
\hline 1 & TKDK & $3.979 .204,17$ & 61.32 \\
2 & Bunga Modal & $2.510 .064,19$ & 38,68 \\
\hline & Jumlah & $6.489 .268,35$ & 100,00 \\
\hline
\end{tabular}

Sumber : Pengolahan Data Primer 2020

\section{Biaya Total}

Biaya total adalah hasil dari nilai tambahan biaya eksplisit dan biaya implisit. Sebenarnya biaya bisa diminimalisir dengan menekan komponen-komponen biaya yang masih bisa diperkecil. Rata-rata Biaya eksplisit sebesar Rp. 3.979.204,17 /petani, Rata-rata Biaya implisit sebesar Rp. 2.510.064,19 /petani, sedangkan Rata-rata Biaya Total sebesar Rp. 6.489.268,35

\section{Penerimaan}

Penerimaan diperoleh dari jumlah hasil panen yang dikali harga jual per kilo, dari hasil wawancara dengan seluruh petani responden diperoleh total rata-rata produksinya adalah sebesar 241,70 $\mathrm{kg} /$ petani dengan harga yang berlaku Rp.50.000/kg. Sedangkan total penerimaan rata-rata sebesar Rp.12.085.000,00.-/petani,

\section{Pendapatan}

Pendapatan masih dapat ditingkatkan dengan mempelajari situasi pasar dan system pemasaran agar memperoleh harga yang memadai. Agar tingkat pendapatan meningkat perlu adanya peningkatan peningkatan efesiensi biaya dan peningkatan penerimaan (TR) melalui peningkatan hasil produksi. Hal ini bias dilaksanakan apabila petani mengetahui penggunaan hubungan antara input dan output. Semakin optimal penggunaan input produksi diharapkan output bisa lebih maksimal.

Hasil analisa, biaya eksplisit rata-rata sebesar Rp.3.979.204,17/petani. Rata-rata penerimaan sebesar Rp.12.085.000,00./petani, Pendapatan rata-rata sebesar Rp.8.105.795,83-/petani.

\section{Keuntungan}

Yang dimaksud dengan keuntungan adalah pengurangan dari penerimaan dikurang biaya total atau biaya keseluruhan. Adapun rata-rata biaya total sebesar Rp. 6.489.268,35/petani, Rata-rata penerimaan sebesar Rp.12.085.000,00.-/petani dan keuntungan rata rata sebanyak $\mathrm{Rp}$. 5.595.731,65/petani.

Sesuai dengan kondisi petani cabai di Desa Pulantan secara umum memiliki permasalahan yang sama dalam membudidayakan padi. Diantaranya minimnya modal yang dimiliki petani, kurangnya pengetahuan petani tentang budidaya tanaman padi. Dalam kondisi seperti ini petani padi sangat memerlukan informasi dan penyuluhan dari petugas lapangan dan instansi teknis terkait. 
Keuntungan akan meningkat apabila jumlah biaya yang dikeluarkan cukup kecil/berkurang. Bila terjadi penekanan biaya dengan di asumsikan harga cabai masih stabil (baik). . Diharapkan output bisa lebih maksimal. Begitu juga sebaliknya jumlah keuntungan akan semakin rendah apabila penggunaan biaya cukup tinggi.

\section{KESIMPULAN DAN SARAN}

\section{Kesimpulan}

Dari hasil penelitian dan analisis data primer mengenai usahatani Cabai di Desa Pulantan , maka dapat diambil kesimpulan sebagai berikut :

1. Dilihat dari teknis penyelenggaraan usahatani Cabai yang diterapkan di Desa Pulantan masih relatif sederhana, ini terlihat dari pengolahan lahan sampai pemeliharaan. Khusus untuk pemeliharaan tanaman, dimana petani dalam penggunaan pupuk belum sesuai dengan anjuran. Produksi yang diperoleh dari usahatani Cabai di Desa Pulantan rata-rata $241,70 \mathrm{~kg} /$ petani.

2. Total penerimaan rata-rata sebesar Rp.12.085.000,00.-/petani. Pendapatan rata-rata sebesar Rp. 8.105.795,83/petani. Sedangkan keuntungan rata rata sebanyak Rp. 5.595.731,65 /petani

\section{Saran}

Berdasarkan hasil penelitian pada usahatani Cabai di Desa Pulantan, maka diambil beberapa saran antara lain sebagai berikut :

1. Untuk menjaga kestabilan harga ditingkat petani agar petani memperoleh keuntungan yang layak dari usahatani, maka peran lembaga pemasaran, pemerintah sangat dipelrukan.

2. Untuk meningkatkan hasil produksi usahatani tanaman cabai, maka perlu perbaikan penyelenggaraan usahatani, penyediaan sarana produksi dan penggunaannya yang sesuai anjuran, penggunaan tenaga kerja yang optimal
3. Sebaiknya dinas terkait terjadwal untuk memberikan penyuluhan pertanian, pelatihan dan kursus intensif yang diperlukan untuk meningkatkan pendidikan, keterampila dan kemampuan petani baik dalam teknis, budidaya maupun aspek manajemen.

4. Peranan penyuluh dan peneliti sebagai motivator pembangunan yang sangat diperlukan oleh masyarakat di pedesaan, oleh karena itu kegiatan penyuluhan hendaknya tetap ada dan bahkan terus ditingkatkan.

\section{DAFTAR PUSTAKA.}

Abd. Rahim dan Riah Retno Dwi Hastuti. 2007. Ekonomika Pertanian, Pengantar Teori dan Kasus : Penebar Swadaya

Ashari, S. 1995. Hortikultura Aspek Budidaya. UI - Press, Jakarta.

Bappenas. 2005. Revitalisasi Pertanian, Perikanan dan Kehutanan (( RKPPK) Buku II. Jakarta.

Desi Natalia Edowai, Stella Kairupan dan Handry Rawung. 2016. Mutu Cabai Rawit (Capsicum frutescens L) Pada Tingkat Kematangan dan Suhu Yang Berbeda Selama Penyimpanan. Jurnal Agrointek Volume 10, No.1 Maret 2016

Fadholi Hermanto, 1994 ; $15 . \quad$ Ilmu Usahatani Cetakan IV. Penebar Swadaya Jakarta.

Fitri Muliati, Andi Ete dan Bahrudin. 2017. Pertumbuhan Dan Hasil Tanam Cabai Rawit (Capsicum frustescens L.) Yang diberi berbagai Pupuk organik dan jenis mulsa. e-J. Agrotekbis 5 (4) : 449 - 457, Agustus 2017

Kasryno, F. 2000, Prospek Pembangunan Ekonomi Pedesaan. Yayasan Obor Indonesia. Jakarta.. 
Mega Silvia, Hilda Susanti, Samharinto, dan Gt. M. Sugian Noor, 2016. Produksi Tanaman Cabe Rawit (Capsicum frutescent L) di Tanah Ultisol Menggunakan Bokashi Sampah Organik Rumah Tangga dan NPK. Jurnal EnviroScienteae Vol. 12 No. 1, April 2016

Muhammad Hatta, 2011. Aplikasi perlakuan permukaan tanah dan jenis bahan organik terhadap indeks pertumbuhan Tanaman cabe rawit. Jurnal. Floratek 6: 18 - 27 Universitas Syiah Kuala Darussalam Banda Aceh

Mubyanto, 1995. Pengantar Ekonomi Pertanian. Edisi Ke-Tiga. LP3E. Jakarta

Nanda Chesaria, Sobir dan Muhamad Syukur.2018. Analisis Keragaan Cabai Rawit Merah (Capsicum frutescens ) Lokal Asal Kediri dan Jember. Buletin Agrohorti 6 (3) : 388 - 396 (2018)

Prajnanta. 2011. Mengatasi Bertanam Cabai, Penebar Swadaya. Jakarta.
Simpson. 2010. Plant Systematics, Elsevier, Burlington, USA, Imc. Publishers, Sunderland, Massachusetts, U.S.A.

Sitompul dan Bambang, 1995. Analisis Pertumbuhan Tanaman, Gadjah Mada University Press, Yogyakarta.

Soekartawi, 1995, Analisis Usaha Tani, UIPress, Jakarta.

Soekartawi, 2002. Ekonomi Mikro. BPEE. Jakarta.

Syarifuddin A. Kasim 1995. Pengantar Ekonomi Produksi Pertanian Universitas Lambung Mangkurat Banjarbaru.

Tjandra, 2011. Panen Cabai Rawit Di Polybag, Cahaya Atma Pustaka, Yogyakarta

Wahyudi, 2011. Panen Cabai Sepanjang Tahun, PT Agromedia Pustaka. Jakarta 